\title{
THE STRATEGY OF NETFLIX TO DOMINATE THE ENTERTAINMENT MEDIA MARKET IN INDONESIA 2016-2021
}

\author{
Atiqa Rana Fergus Putri ${ }^{1}$, Arie Kusuma Paksi ${ }^{2}$ \\ 1,2Universitas Muhammadiyah Yogyakarta \\ atiqa.rana.fisip18@mail.umy.ac.id
}

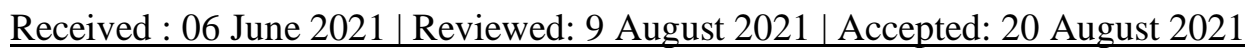

\begin{abstract}
ABSTRAK
Perusahaan multinasional (MNCs) merupakan aktor non-negara yang memiliki peran penting dalam hubungan internasional. Globalisasi telah memfasilitasi perkembangan perusahaan multinasional serta transformasi media. Hal ini berdampak kepada hadirnya perusahaan multinasional berbasis media hiburan yang beroperasi dengan sistem SVOD (Subscription video-on-demand) seperti Netflix. Netflix memilih Indonesia sebagai salah satu pasar potensialnya. Namun, Netflix harus menghadapi pesaing baru dan menyelesaikan beberapa kendala dan peraturan yang datang dari perusahaan lain dan pemerintah di Indonesia. Penelitian ini bertujuan untuk mengetahui dan menganalisis strategi Netflix dalam menguasai pasar Media Hiburan di Indonesia dengan konsep MNC, strategi Internasional, dan keunggulan bersaing. Penelitian ini menggunakan pendekatan kualitatif dengan metode deskriptif dimana pengumpulan data berasal dari data sekunder seperti buku, literatur akademik, dan portal berita. Dalam menganalisis data, peneliti mengkaji dan menarik penjelasan mengenai fenomena tersebut. Strategi dan upaya yang dilakukan Netflix mampu menjadikan Netflix sebagai platform SVOD pilihan nomor satu di pasar Indonesia. Hal ini didasari atas supremasi yang dimiliki Netflix, terutama dalam menyediakan konten original. Dengan terus mengembangkan strateginya, Netflix dapat terus menginternasionalkan layanan produknya di pasar Indonesia.
\end{abstract}

Kata Kunci: Netflix, Strategi, Subscription Video on Demand (SVOD), Indonesia, Perusahaan Multinational

\footnotetext{
ABSTRACT

Multinational corporations (MNCs) are non-state actors who have a significant role in international relations. Globalization has facilitated the development of MNCs as well as the transformation of media. It impacts the presence of multinational entertainment media companies operating with the SVOD (Subscription video-on-demand) system like Netflix. Netflix chooses Indonesia as one of its potential markets. However, Netflix has to face new competitors and resolve several obstacles and regulations from other companies and governments in Indonesia. This research aims to find out and analyze the strategy of Netflix is dominating the Entertainment Media market in Indonesia with the concept of MNC, international strategy, and competitive advantages. This research used a qualitative approach with descriptive methods where the data collection came from secondary data such as books, Korespondensi:

Universitas Muhammadiyah Yogyakarta

Jl. Brawijaya, Geblagan, Tamantirto, Kec. Kasihan,

Bantul, Daerah Istimewa Yogyakarta 55183uRNAL ILMIAH DINAMIKA SOSIAL 5 (1) 2021 | 110

E-mail: atiqa.rana.fisip18@mail.umy.ac.id
} 
academic literature, and news portals. In data analysis, the researcher reviewing and draw an explanation regarding the phenomenon. The strategies and efforts made by Netflix can make Netflix become the number one choice for the SVOD platform in the Indonesian market based on the supremacy that Netflix has, especially in providing original content. By developing its strategy, Netflix can continue to internationalize its product services in the Indonesian market.

Keywords: Netflix, Strategy, Subscription Video on Demand (SVOD), Indonesia, Multinational Corporations $(M N C)$

\section{INTRODUCTION}

The scope of international relations is no longer limited to state-to-state actors, but nonstate actors also play their role in the international system. A multinational corporation (MNC) or multinational company is a non-state actor defined as a company with facilities and assets other than its country of origin. Multinational corporations have several forms, consisting of large companies that can manage their subsidiaries in several countries to small companies investing abroad (Mayrhofer \& Prange, 2015). We can see a multinational company's significant operating activities from the operations that simultaneously control the flow of capital strength, sound management systems, and technology (NST, 2014). Multinational corporations have several categories based on their respective industrial sectors: multinational food corporations, multinational health corporations, multinational breweries, and multinational mass media corporations. As a company that develops in international markets and operates across countries, multinational corporations have become essential and have increased in the last few decades. The development of information and digital technology that focuses on the use of the internet has brought a new form of focus for the development of multinational corporations. Digital technology can help these companies break free from geographic boundaries and the costs of building a physical presence in a foreign country (Nachum \& Zaheer, 2002). Moreover, the company founders also saw another opportunity where the human need for entertainment encouraged multinational corporations in the entertainment sector to continue to proliferate by providing various forms of a broad spectrum of media such as music and movies (Kusuma, 2019).

Netflix is a multinational digital service company from America engaged in the entertainment and media sector that offers various kinds of original films to popular films whose content focuses on video-on-demand services where the consumer can access streaming content via the internet (Ruether, 2020). This company has spread to 190 countries with a 
subscriber number of over 100 million. This company wants to continue growing and striving to compete in the entertainment media video-on-demand streaming market with its success so far. With the advancing times, several competitors have emerged with the same services like Netflix, namely Disney+, VIU, Hooq, etc., that can trigger Netflix to continue to innovate. In its expansion, Netflix chooses Southeast Asia to be one of the target markets, especially Indonesia. With the large population and the large number of internet users reaching 132 million and internet access via mobile amounting to 371 million, this data makes Netflix see Indonesia as a very potential market. Netflix first entered Indonesia in 2016 and became the first company on VOD services to enter Indonesia (Nugroho, 2017). However, in its development, Netflix had to go through a complex dynamic where several parties immediately blocked Netflix since Netflix entered Indonesia.

In its development, Netflix had a good impact, especially during the pandemic where Netflix managed to get a sizeable increase in subscribers. During the pandemic, Netflix has successfully added 16 million new subscribers globally (Leba, 2020). This significant increase does drive because of the public facilities that are closed. On the other hand, Netflix is also diligent in providing original content such as films and series from various countries, so it's not limited to western content. However, Netflix's success in getting many subscribers also faces challenges because several similar companies are also expanding to dominate the digital entertainment sector. Netflix must compete against its competitors, namely with other streaming Subscription Video-On-demand (SVOD) platform companies such as Disney+, VIU, Iflix, and others, who also wanted to dominate the Indonesian entertainment media market. With a market ripe for the rapid growth of digital streaming platforms, it has launched Netflix competitors, especially Disney+, as a significant battleground (Kontan, 2020). Thus, behind their success and the positive impact Netflix has received, they must also carefully arrange the plan and use its courage to embody a different innovation to compete and reach their goals.

Netflix has become a platform that has been in the hype lately. It also makes Netflix an exciting research theme to study. The study conducted by Dias \& Navarro (2018:, p. 19) cited that Netflix's effort to consolidate the Brazilian streaming video content market (Over-the-Top - OTT) has to overcome obstacles and challenges such as the Brazilian economic recession accusations of tax evasion against Netflix. However, Netflix can handle it quite well as Netflix 
can still face intense local competition. Meanwhile, research conducted by Scarlata (2020: , pp. 1-2) stated the impact of Netflix as a global subscription video-on-demand (SVOD) service in Australia, which using a screen-ecological perspective to understand the dynamics of culture and industry on the supply and demand side of the impact of multinational SVOD services in Australia. In addition, the study results also show that there are differences in the internationalization model of Netflix, which, if we are not good at reading it, will have implications for maximizing opportunities for the international streaming industry in Australia.

The final part, Indrayani \& Ramadhanty (2020:, p. 7917), examines that Indonesia is one of the targets of Apple Inc's control as an actor of MNCs. However, to dominate the technology market in Indonesia, the multinational company Apple Inc must compete with its competitors to draw up strategies to achieve the goals of the Apple Inc company. Although there was a previous review regarding research on Netflix's expansion as a multinational company into a country, however, previous authors only revealed Netflix's efforts to dominate the SVOD market and the impact of Netflix in a few countries. No one has yet researched it in Indonesia, because as we know, every country has different regulations, barriers, and challenges. Moreover, although previous studies have examined the same theme regarding the strategy of a multinational company in controlling a market in Indonesia, the focus on the MNCs figures is different.

This journal attempts to explain and analyze how the strategy carried out by Netflix in competing and facing its challenges to achieve the goal of dominating the Indonesian entertainment media SVOD market using a multinational corporation concept that focuses on Netflix's internationalization and competitive advantages. As one of the multinational corporations engaged in digital streaming, although Netflix has succeeded in dominating the global market, new competitors are here to compete with Netflix to advance technology and era. Moreover, when Netflix entered Indonesia, they faced obstacles that could not be arbitrary because they had to comply with several existing regulations and received criticism from several other mass media companies. Thus, the authors are interested in raising and presenting how Netflix can survive to achieve its goals. The authors can attain those two objectives with the question that guided this study: How is the Netflix strategy to dominate SVOD (Subscription Video on Demand) entertainment market in Indonesia? 


\section{THEORETICAL FRAMEWORK}

\section{Concept of Multinational Corporations (MNC) and Market Competition}

This study tries to discuss MNC as an actor in international relations. In developing their companies in various countries, multinational corporations have their own goals. In general, their purpose is to achieve more significant profit potential by carrying out production activities abroad. The expansion of the market and the company's actions will result in higher profit potential for multinational corporations. The following is an explanation of the objectives of multinational corporations to dissect in more detail. There are; market seekers who aim to find or gain new market share in other countries. Second is the cost minimizer seeker, which will enable the multinational corporation to achieve cost efficiency due to investments that will increase the presentation to obtain lower production costs. Then risk minimizer seeker to reduce the risk of production and sales, these multinational corporations can look for new places in other countries. Finally, strengthening the company structure is a fundamental goal. MNCs must also enhance their entities to make their companies in countries abroad utilize the company knowledge (Kurniananda \& Jaludallasa, 2020).

According to Johanson \& Vahlne (1997: , p. 23), the notion of internationalization is a process for a company to increase its involvement in the international world. In the context of international business, internationalization is the development of a company to expand and develop in foreign markets (Jane, 2012). The company has its international strategy to adjust and manage the differences when it operates in different countries and with its cultural borders. In this study, the transnational strategy was chosen as the compatible strategy as this strategy is a hybrid to get a good response in the local and global scope. By operating in many countries, a company will receive great benefits and profits. In carrying out this strategy, the company can't quickly adapt and standardize a product simultaneously, so they have to make trade-offs by implementing a complex organizational structure to generate ideas from local operations to integrate it with global standards. This strategy has the primary function of getting high local responsiveness that intends to explore the local market in their operation areas by finding out the needs of local customers. In the future, companies will create additional services according to the needs of local customers where they operate regularly, offering global products (Saxena, 2020). 
In the process, Netflix must also develop a mature strategy to outperform its competitors and create a competitive advantage. Cited from Rita (2019), Michael Porter said that competitive advantage must explain and instill business value to consumers to form a different perception in the eyes of consumers. Every company must have its benefits, but maximizing its advantages to achieve profits is the most critical thing. Porter offers several essential points that can reference a company as one of its strategies to increase its competitive advantages. The first strategy provided is cost leadership, which is how a company can achieve and take advantage of economies of scale to produce higher volumes but at lower costs. By lowering or reducing costs, the company can achieve dominance among its competitors and earn greater profits. The second is differentiation which, in this case, a company must build good branding in terms of solid internal skills such as improving the technology used and creating unique products. This strategy aims to create a different product from the others and makes it difficult to imitate. The third is market segmentation or focus, which has a narrow scope. In this case, the company must focus on finding specific consumer target markets not utilized by large companies (Tanwar, 2013).

Industry 4.0 has created many new players in MNCs that focus on digital services, trying to expand and dominate various markets globally. Based on the above explanation, this study will discuss two main strategies that Netflix company applies to compete in the entertainment industry. Particularly important is the decision by Netflix to internationalize to Indonesia, which will expand Netflix's consumer market. As a company that produces and distributes movie content, Netflix must struggle to be more competitive than its competitors and earn their competitive advantages. Therefore, we want to look at how Netflix copes with the competitive entertainment market in Indonesia.

\section{RESEARCH METHODS}

The authors chose a qualitative approach to explain the phenomenon in Netflix's strategy in dominating the entertainment media market that provides SVOD services in Indonesia. Qualitative research will produce a written descriptive data that allows it to be observed. This qualitative approach adopts descriptive methods to obtain, explain, and analyze the current status phenomenon through various techniques (Satriadi, 2014). The data collection primarily uses secondary data collected from the existing data by selecting some sources in the form of 
text, where the researcher will analyze the data later. Netflix becomes the subject of this research that has a source of information. Therefore, the data source comes from academic literature, news portal, and journalistic articles that aim to interpret the related issues more precisely and have a comprehensive analysis. These data and information will be reviewed and analyzed to derive an explanation about the phenomenon that can obtain answers to the problems under the study and drive conclusions based on the essential points.

\section{DISCUSSION}

This chapter will explain the research findings of Netflix's strategy to dominate the entertainment market industry in Indonesia. The discussion will be divided into four subchapter to define it more precisely. The first part is the dynamics of Netflix's development in Indonesia from 2016 until 2021 that talked about the advancement of Netflix in Indonesia since the beginning of Netflix's entry into Indonesia, until the recent year, wherein its progress Netflix faced several obstacles and challenges. The second part is Netflix and its competitors in Indonesia, namely Disney+ and VIU. This part is focusing more on Netflix's strengths and weaknesses in Indonesia. The third part of the sub-chapter is Netflix's strategy and efforts as an MNC during 2016-2021 In Indonesia that emphasized and implemented the theory of MNC into Netflix's processes. The last part, which is Netflix's strategy to survive during the pandemic, is concerned with the system done by Netflix in facing the current pandemic situation. Before explaining the whole point, the next part will first discuss the dynamics of Netflix's development in Indonesia from 2016 until 2021.

\section{The Dynamics of Netflix's Development in Indonesia from 2016 Until 2021}

January 7, 2016, become the official date for Netflix to enter the Indonesian market. This shows that Netflix's range of investments became wider. Netflix is the first SVOD company to expand its wings in the Indonesian market. Netflix's expansion to Indonesia brings pros and cons from several parties. PROFI (Asosiasi Produser Film Indonesia) as a Homeland industry gives an excellent response to Netflix where they think that the presence of Netflix can provide new hope to the movies industry in Indonesia by providing new space for filmmakers in Indonesia as well as a new impression on Indonesian consumers (Jamaludin, 2016). Other parties who responded well to the arrival of Netflix are the operator services such as Smartfren and XL that argued Netflix would provide added value to customers in Indonesia and bring 
new variations in using the $4 \mathrm{G}$ internet network in Indonesia that the subscribers could access to browse a lot of content faster (Iskandar, 2016).

On the other hand, Netflix's fame and status as a new giant in the entertainment world has made television, internet service providers, and several other parties in Indonesia feel threatened. This concern can be proven from the action by PT Telkom as an internet provider company. A few days after Netflix's entry into Indonesia, this company immediately blocked Netflix from its internet services, such as Wifi.id, Indi home, and the cellular operator Telkomsel. This company gives a reason behind the blocking action caused by the content owned by Netflix has pornographic and radical elements which are not inherent with Indonesian regulations (Bate, 2018). This biased decision is considered too hasty because compared with other platforms such as YouTube or Twitter, where they are free to access and accessible to anyone, of course, it is far more dangerous than Netflix. However, the Telkom group's opinion on Netflix is not entirely wrong because it is true that at first, the distribution of Netflix's content in Indonesia had not been censored by the government and national censorship institutions. However, these reasons cannot be used as an excuse for blocking Netflix because it is not entirely the Netflix company's fault.

Another thing has Netflix considered a digital streaming company that takes advantage of the telecommunications operator network. The Telkom group feels that Netflix is detrimental because the internet quota needed to access Netflix is extensive. It takes 3 gigabytes of the quota to access full high-definition movies for one hour. Telkom Group felt that they are only used as a dump-pipe without any benefits (Wibisono, 2016). However, according to the author, the internet provider company - is the party that will get the benefits because accessing Netflix itself requires the internet. Netflix customers who want to watch their content must provide good WIFI internet and internet quota that makes customers will be prepared it first by buying in advance from the internet provider company.

Nevertheless, one by one, the parties who gave negative responses have changed their perspective on Netflix over time. It took four years for Telkom group to open its access to Netflix, which officially opened in 2020. This is based on the efforts made by Netflix itself to be accepted by those who oppose it, such as limiting inappropriate content, presenting features information on adult content, and Netflix receives all complaints and feedback for 24 hours 
(Kompas, 2020). In addition, every year, the number of Netflix subscribers in Indonesia is increasing rapidly.

Figure 1 Netflix's subscribers in Indonesia 2017-2020

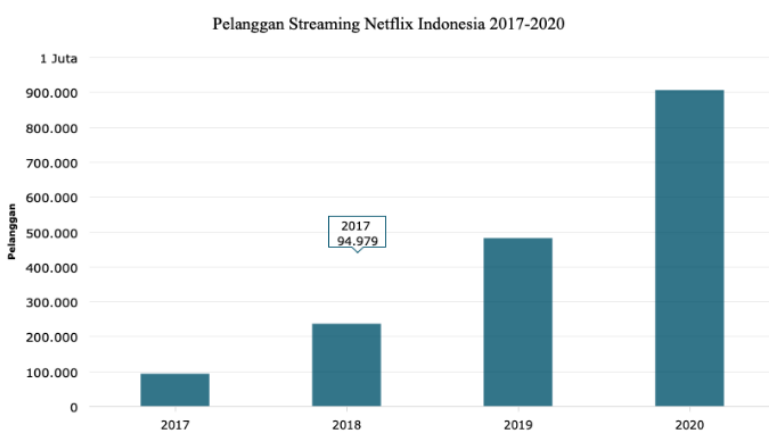

Source: https://databoks.katadata.co.id/

According to nakono.com (2019) data, the total Netflix subscribers in 2017 reached 95 thousand subscribers. The following year, namely 2018, total Netflix subscribers reached 237.3 thousand, which increased by 2.5 times. Until 2019, the number of Netflix subscribers continues to grow to 481,450 subscribers. During the 2020-2021 pandemic, Netflix subscribers globally increased rapidly, with 15.77 million new subscribers. However, it turns out that the impact of the pandemic on the increasing numbers of Netflix's subscribers in Indonesia has shown less than optimal results due to the number of competitors that consumers prefer. There has indeed been a rapid increase in Netflix subscribers if we look at it globally. Asia Pacific market accounted for the most subscribers. However, in Indonesia itself, Netflix subscribers in the first quarter of 2021 were only 850 thousand, less than Disney+, which already has more than 2.5 million subscribers since entering the Indonesian market in September 2020 (Jemadu, 2021).

From this, we can see those other companies that inhibit the arrival of Netflix in Indonesia are based on their concern about Netflix because they know that Netflix has its superior value that can beat them. Meanwhile, according to the authors, the government's response to the entry of Netflix in Indonesia can be said as a cautious response and steps because the government does not directly determine its policy on Netflix but is still reviewing more deeply and discussing the impact of Netflix's entry into Indonesia. The results of the data also shown a 
good level where Netflix customers increase every year. Even though many Netflix competitors appeared during the pandemic that hampered and decreased the number of new Netflix subscribers in Indonesia, this cannot be a conclusion that Netflix accepted its defeat.

\section{Netflix and Their Competitors in Indonesia}

With the rapid growth of the internet used to disseminate, people can access all information or entertainment through digital media. It makes many film industries are utilizing technology with a subscription video-on-demand (SVOD) system. This service comes from its roots, namely VOD or video-on-demand, where film, series, video content is distributed unscheduled. The technology system allows users to access content by buying or subscribing and downloading from several digital streaming platform distributions such as Netflix, Amazon Prime Video, Disney+, Hulu, etc. (Allroll, 2020). SVOD or subscription video on demand is a form of VOD present as a system in a digital streaming platform where users must subscribe first if they want to watch the content provided. In addition, the SVOD system also offers free time access at any time for users who want to watch movies content without any particular schedule, and users have complete control over this system service. They are also exempt from any contracts that make the customer can freely stop the service extension.

One company engaged in the SVOD services system is Netflix, a pioneer and one of the golden examples. However, with the transformation of media towards digital because of advances in technology innovation and the availability of internet access, many SVOD platform service companies have emerged and competed with each other. Netflix Inc is an American company founded in 1997 by Reed Hastings with its initial role as an online-based movie rental place where everyone can order DVDs and watch movies they wanted which they have registered on a list first. Then Netflix will send the DVD movies to their homes. Until 2013, the "House of Cards" series was introduced by Netflix as their first original series. Respectively, with its function of providing "online video on demand," Netflix is free from advertisements and makes the subscribers free to choose the content or video they want to watch. Over time, this company has grown and expanded to various countries globally and become one of the world's largest online movie streaming platforms, available in 190 countries, including Indonesia, with more than 80 million subscribers (Munandar \& Tambunan, 2018). Netflix has several films and offering packages that range from mobile packages for IDR 
54,000 / month, which can only be accessed by one phone or tablet device, to the most expensive package, which is premium for IDR 186,000 / month can be seen with four different devices at the same time (Aulia, 2021).

Moreover, Netflix continues to produce original films and series. In this regard, Netflix expanded not only for its platform of content but also against its list of competitors. The authors chose the most competitors' platforms competing with Netflix in the Southeast Asia region, especially Indonesia, to examine more deeply.

Disney+ Hot star is one of the strongest competitors for Netflix in the international and regional context in Indonesia. The content provided by Disney+ ranges from masterpiece animated content, documentaries, Star Wars film series, and other films provided up to 500 movies and special events. One of the advantages of Disney+ is that they collaborate with Marvel Cinematic to release series titled superhero marvels such as "Wanda vision" and a vast library of Disney channel films, and with the acquisition of Fox by Disney, the absence of content from popular shows such as "The Simpsons." Besides the content, the subscription price offered by Disney+ is also more affordable, namely IDR 15,000 / 1 month and IDR 30,000 / 3 months (Abbot, 2020). Compared with Netflix, Netflix cannot provide authentic content and re-create classic Disney animated content. By giving different content with lower prices, Disney+ hot star gets many subscribers in Indonesia. Asian media partners estimate that Disney+ hot star has succeeded in controlling 2.5 million subscribers in the Indonesian market share, while Netflix has 850 thousand subscribers (Damar, 2021).

Another less competitor is VIU, founded by Hong Kong's largest telecommunication company PCCW and launched in 2015. Besides providing Hollywood films, this platform focuses on Asian series and movies, especially from Korea, China, Indonesia, Japan, and Taiwan. For the subscriptions, VIU offers several packages that are more practical at a more affordable price. VIU provides weekly packages starting from IDR 10,000 / week, monthly; IDR 30,000 / month, and IDR45,000 / 3 months. All packages can be accessed using one account for a maximum of 5 devices (Stephanie, 2020). According to the author, the predominance of VIU itself compared to Netflix is beside the lower price. The Korean dramas and Korean shows are constantly updated and exclusively aired on VIU for approximately 8 hours after airing in the home country. The content will come with English subtitles. As we 
know, the Korean wave phenomenon is on the rise in the global world to Indonesia, which impacts people's interest in watching Korean content. The availability of content provided by VIU can attract Indonesian consumers' attention, especially Korean dramas presented by VIU are continually updated following developments that also occur in Korea itself.

\section{Netflix's Strategy and Efforts During 2016-2021 In Indonesia}

In this research, the authors will emphasize the strategy done by Netflix to dominate the Indonesian entertainment media market into three kinds of parts: the international strategy as Netflix's internationalization process, Competitive advantages, and the effort made by Netflix in facing Problems in the Indonesian Market. However, the discussion will start by examining Netflix inc. as a Multinational Corporation (MNC).

Netflix inc. is a multinational company originating from the United States engaged in SVOD services, which is expanding and has subsidiaries in various countries, including Indonesia, by spreading production or trade in the form of film content provision services and company activities in Indonesia. For that, Netflix can be categorized as a multinational, internationally owned enterprise (MOE). In the concept of an international company, even though Netflix Inc originates from America, this company must still follow the policies, laws, and norms that apply in Indonesia (Indrayani \& Ramadhanty, 2020). With the headquarters located in Los Gatos, California, Netflix Inc is an American multinational SVOD service that provides the video-on-demand system with a wide variety of original and non-original film content. Before discussing further, the strategy or efforts by Netflix, the author will review Netflix's specific goals in expanding to other countries.

1. Market seeker: Netflix uses technological developments and innovations as a weapon of opportunity to gain new shares in other countries. With intense competition in the United States market, Netflix is shifting its focus to the Asia Pacific market, one of Indonesia, which has great potential based on the high use of the internet and digital video viewers.

2. Cost minimizer seeker: To achieve efficiency in production costs, Netflix Inc invests in Indonesia in quality content of films and TV series.

3. Risk minimizer seeker: In this case, Netflix can reduce the risk of production and sales, where the company is looking for new locations in other countries. 
4. Strengthening corporate structure: To maintain its corporate system, Netflix serves overseas markets by establishing itself as a substantial entity by leveraging Netflix's innovations and ideas in Indonesia.

Netflix Inc company operates in two or more countries whose destinations and centers are in their home country. MNCs are expanding to various countries, especially developing countries. Meanwhile, developed countries such as America and Europe still dominate as the home country. As a multinational company, Netflix's existence has an influence, especially on developing countries like Indonesia. Moreover, Netflix has created a decentralized organizational structure in which they have an open-discussions about strategy and results. The decision-making process is also carried out through joint adjustments. However, for distributing its products and services, Netflix still relies on a centralized system where content creators have to go through several regulations, checks and agree to Netflix's privacy. Netflix has complete control over the production and distribution of its content (Virk, 2018). The obstacles and criticism received by Netflix and the number of new competitors have not deterred its intention to dominate the SVOD services in the entertainment media market in Indonesia. Netflix Arranges various strategies as well as efforts to show the superiority of the company.

\section{a. International Strategy as the Process of Internationalization of Netflix Expansion}

Internationalization is a process carried out by a company to develop and be involved in the international world. The effect of globalization has made many companies internationalize their production, marketing, and their sources. However, another thing that affects internationalization is the development of technology that has encouraged communication, information, and production methods to contribute to international trade. Seeing this, Netflix's move to internationalize its company is one of its activities as a multinational company. As one of the profitable strategies for Netflix, the internationalization of Netflix has succeeded in bringing the company to the world with direct customer-to-consumer connections obtained from 150 million subscribers worldwide.

In expanding their company, Netflix reflects on the traditional expansion model in which they will find other appropriate strategies to develop their company into the global market. Netflix must also choose its target market carefully. Netflix strives to be able to make the most of the possible opportunities. Netflix will choose a country with the same consumer appeal or 
a similar culture, and internet users are also essential to pay attention to, making it easier for Netflix to expand into that country. Apart from opportunities, Netflix must also be able to read and study the situation in the target country, such as knowing the consumer fondness in preparation for dealing with regulatory policies of each target country and the most effective marketing methods. That phase makes as what Netflix has now.

The transnational strategy is the right strategy to describe the internationalization process of Netflix because Netflix does not only focus on expanding to other countries, but Netflix also maintains its position in the local Indonesian market. Moreover, under the goal of high local responsiveness wherein meeting the demands of local customers, Netflix publishes content according to the needs of local customers so that Netflix can meet the standard of the local market. In Indonesia, Netflix produces "June \& Kopi" as its original films. They also try to distribute other Indonesian films such as "Ada Apa Dengan Cinta" and other films that Netflix subscribers in Indonesia can enjoy. However, the content is not only added for the countries where Netflix operates because Netflix also continues to provide its global movie services that can be enjoyed by all customers globally.

\section{b. Competitive Advantages of Netflix}

The advancement of the internet and technological transformation creates more multinational SVOD services expanding and competing with Netflix. They use each other's strengths to lobby each other and to be accepted by their host country. Companies are almost always in competition with each other in seeking the number of customers and revenue. For that, every company must have its competitive advantage to achieve its benefits. As Porter offered, there are three competitive advantages: cost leadership, differentiation, and market segmentation.

Moreover, Netflix's strategies focus on three things, namely expenditure, content, and user experience. Cost leadership means that a company should assign lower costs than competitors as its competitive advantage. However, Netflix does not fully use cost reduction in its competitive advantage strategy. Netflix sets prices that remain competitive among its competitors. Netflix offers several packages such as premium and basic packages that can be an option for customers who want to subscribe. In expanding the number of customers, competitive pricing becomes one of the opportunities. 
In addition, there is one of the main strategies in developing competitive advantage, namely differentiation. Netflix uses this strategy in expanding its global market share, where Netflix builds its internal skills strongly by improving technology and innovation in producing its content. The type of original content produced by Netflix and the high quality of films make this difficult for the competitors to imitate it. Netflix has known for its outstanding original content originating in various countries. So that, the investment and approach taken by Netflix in its target market countries, including Indonesia, is to produce original films based on local content. By collaborating with production houses in Indonesia, Netflix also connects copyright agreements to stream titles in each region with the original studio (Rosenberg, 2021). One of the actual contents that have been produced is "The Night Comes for Us." Netflix does this to adapt to the Indonesian national market. The investment of resources spent by Netflix in its host country is developing new content every year. Netflix carries out this strategy to encourage future growth and content with lasting value. Netflix's focus on original content is also a form of long-term cost savings. Therefore, Netflix does not hesitate to invest heavily in producing this content (Penamatsa, 2018).

Market segmentation or focus became the last strategy offered by Porter where here Netflix should focus on finding their potential customer or market. In the case of Netflix, they choose Indonesia to expand their product and services. It is an excellent strategy because Indonesia has become a potential market where the number of internet users in Indonesia is high. Apart from that, user experience also becomes the focus of Netflix, which is highly prioritized. To retain users, Netflix does not mix advertising content. It provides unique features such as downloading content so that users can access it without having to be connected to the internet. Netflix considers the service without advertising to achieve customer satisfaction more important than getting additional benefits through advertising (Lovely, 2018).

\section{c. Netflix's effort in Overcoming Problems in Indonesian Market}

Despite the three components of the Netflix strategy, Netflix also seeks to respond to various obstacles when entering the Indonesian national market. Localization of the country origin language subtitles is one of Netflix's efforts in its international growth. The language barrier where many Netflix content initially did not have Indonesian subtitles has become a concerning issue. For this reason, localization of subtitles is essential for Netflix to engage with Indonesian customers. Netflix has been realizing, where some original popular content such as 
"To All the Boys I've Loved Before” and "Stranger Things” series have Indonesian subtitles (Pertiwi, 2018). Another obstacle is Netflix have to comply with the regulation or policy in Indonesia. Since the first time Netflix entered Indonesia, several parties oppose it because its content is not suitable with Indonesia's policies. In facing the regulation by Indonesia, Netflix has to maintain the deals of censorship. Netflix has not done censorship completely, but Netflix is trying to do the censorship independently by providing services; age and maturity rating labels where viewers can determine whether the film contains violence, sex, adult language, nudity, and other non-appropriate things. Netflix also describes the content of the film or series and provides reporting services for system violations.

Payment methods also become problems, which previously the subscribers could only pay by using a credit card, which in Indonesia, not all people have a credit card. However, Netflix strives to cooperate with operators in Indonesia such as Smartfren, XL, Bolt, Tri by providing a video streaming subscription data package. Payment can also be made by debit card, Master Card, Visa, and American Express logo. Netflix has also collaborated with a digital genius application (Kumparan, 2020). The opening of Netflix access by the Telkom group is also a result of the efforts or approaches made by Netflix. Netflix has taken this approach by providing various features such as parental controls to limit shows that are not suitable for viewing by underage users. Through the "Self-Regulatory Code for Subscription Video on Demand Industry in ASEAN" shows that Netflix has also agreed on a commitment to compliance as a form of compliance with Indonesian regulations where Netflix agrees not to broadcast content with elements of child pornography, content that violates Intellectual Property Rights (IPR), content with aspects of racism, and content on terrorism (Clinten, 2020). In terms of approaching the Indonesian government, Netflix has invested 1 million US dollars or equal to 14 trillion Rupiah, which is aimed at initiative activities such as scriptwriting training for Indonesian creators to develop film talent in Indonesia, which was formed through Netflix's partnership with the Ministry of Education and Culture. In addition, Netflix also builds partnerships with content creators and film activists in Indonesia to continue creating local Indonesian content that consumers can access exclusively on Netflix (Eka, 2020).

\section{Netflix's Strategy to Survive During Pandemic}


The COVID-19 pandemic has accelerated the transformation of companies from debtridden digital companies to an essential part of the TV landscape in homes worldwide. Netflix has added 170 million subscribers in more than 190 countries, and the results triggered by the pandemic brought Netflix's market value to an all-time high of $\$ 259$ billion. 2020 is proving to be the best year in the company's history, even as a new wave of well-funded rivals is trying to take its streaming crown.

\section{Figure 2 Netflix' Paid Subscribers Growth}

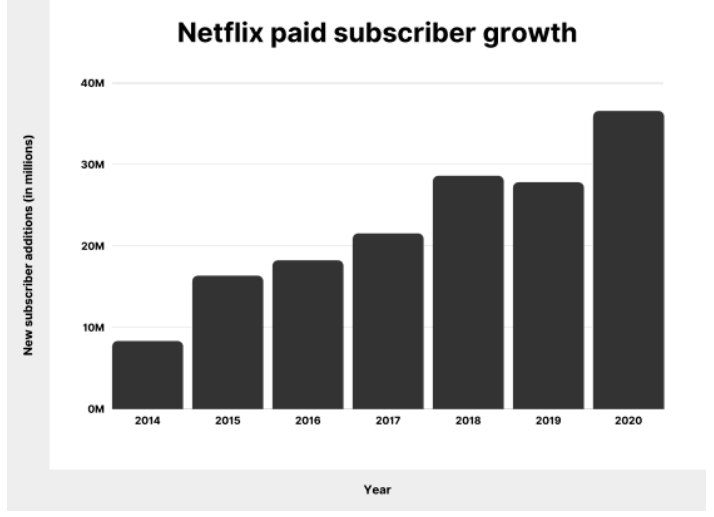

Source: https://backlinko.com/netflix-users

According to figure 2, Netflix added a record +/- 37 million new subscribers accustomed to operating in combat mode. Compared to the previous year, Netflix has added $31.4 \%$ for its subscribers due to lockdowns that pushed subscribers to stay indoors to provide new movies and series such as The Crown, Bridgerton, and The Queen's Gambit were able to make Netflix leading in streaming services platform. Netflix also added 100.97 million new members as their new subscribers (Dean, 2021).

In these challenging times of pandemic, Netflix seeks opportunities by providing a source of connection, fun, and escape content to the customer in Indonesia. To keep developing, Netflix puts intensely in their original shows and movies to make itself an unquestionable requirement to have competitive administration in an undeniably cutthroat streaming business sector. For post-production, Netflix already has more than 500 titles set up for release on the service, with plans to release at least one new original every week. From comedy, science fiction, drama to horror mystery, the film list will take on every primary film genre. With 
several films ready for release as ammunition for competitive competition to get big awards (Times, 2021).

Perhaps during a pandemic, Netflix experienced a decline in subscribers in Indonesia, but the author still believes that Netflix will still be superior. This is based on that Netflix always does what it needs to do. Although it has shifted mainly to streaming its content, Netflix will license projects where possible, as was the case with Korean thrillers "Time to Hunt" and romantic comedies "The Lovebirds" and "Enola Holmes." This takeaway suggests that other studios may want to compete with Netflix, but they don't have the proper infrastructure in any sense. Netflix releases all of its shows at once until Netflix starts experimenting with staggered releases, as it does with the unscripted hit "Love Is Blind." With the new social distancing policy that made the cinema closed, Netflix didn't have any worries because they did not release its theatre content (Alexander, 2020). Netflix used only to have one way to buy a service and rely on the growth of the internet, so it offers a cheaper way to countries such as India, Indonesia, and the Philippines. Netflix used to refuse to tell anyone how they did the show. Now Netflix shares the top 10 most popular programs on the service and is cementing growing series. In terms of this, no other competitor can come close to operating at the level of Netflix.

Moreover, Netflix's rivals such as Disney+, Iflix, VIU, Amazon prime, or any other platform-based internet will be more difficult to survive a pandemic as they are very dependent on ad revenue. Meanwhile, Netflix is not reliant on ad revenue. Moreover, how is advertising related to the coronavirus? If the economy goes into recession, the first thing companies will do cut advertising budgets. If the ad budget is lost, platforms like Facebook, Google, Disney, and Snap may see their ad revenue drop.

In contrast to Netflix, Netflix is the only entertainment media company that does not depend on ad revenue because its revenue came from the subscription-based. In addition, people will need something to entertain them due to the stay-home activities as the spread of coronavirus. Thus, it makes sense that the subscriber of Netflix could increase as the pandemic rages (Grothaus, 2020). 


\section{CONCLUSION}

Netflix's market expansion as a multinational entertainment media company with its internationalization strategy has yielded significant results. The innovation and technology owned by Netflix as a company that produces content are always needed. Netflix produces its innovative products by looking at the demand in the market while remaining focused on its strategy. During its formation, this company has received a lot of increasing demand, especially in a pandemic; Netflix is needed to be a source of human entertainment. For this reason, Netflix has prepared a variety of film and series content to meet consumer needs in Indonesia and throughout the world. Indonesia is a cellular-centric market that has become a target for various SVOD service companies. A mature strategy is what Netflix needs to stay ahead of its competitors. The enormous content supply and the absence of advertisements on the Netflix platform are its advantages, saving this company in various situations, even in this pandemic situation. This strategy carried out by Netflix has made them become an entertainment platform offerings high-quality exclusive content that subscribers can only see exclusively on the Netflix platform, which attracts subscribers' attention to come back and watch more original content.

In addition, the approach that Netflix has taken to several parties, including the Indonesian government, can be said as a successful way. The partnership between Netflix and the Indonesian government is a win-win solution because both parties can get their respective benefits. It will make it easier for Netflix to dominate the Indonesian market. At the same time, Indonesia can develop and improve its films' quality since Netflix has successfully solved certain matters in Indonesia that lead them to dominate the Indonesian entertainment market. The authors expect that Netflix can maintain its position in Indonesia by collaborating with Indonesian providers or any other parties and the government in Indonesia. Netflix should be able to create more Indonesian movies and improve the quality of the creative industry in Indonesia so that Indonesian films can compete with foreign films in the global market. Moreover, there are still several movie piracies in the Indonesian case, for that Netflix should strengthen out their security services to avoid piracy.

However, this study still has slight obstacles regarding the lack of the resource data of Netflix strategies in dominating the Indonesian entertainment media market. The data available is mainly obtained from internet websites or news portals on the internet. There are still few journal articles that research or raise the theme of Netflix control in Indonesia. In addition, if 
there is any related data, it is difficult for the author to access the data due to the limitation of public access. In this way, open access to sources of information and data related to Netflix, especially its growth in Indonesia, is needed for further research. The interest in discussing the Netflix subject in Indonesia is expected to provide new insights from different perspectives.

\section{REFERENCES}

\section{Books:}

Penamatsa, V. (2018). Netflix Inc A Strategic Analysis. Boston, United States of America: Northern University.

\section{Article In Journals:}

Bate, A. P. (2018, May ). Resistensi Telkom Terhadap Netflix dalam Industri On Demand Streaming Service di Indonesia. 10-13.

Dias, M., \& Navarro, R. (2018, January). Is Netflix Dominating Brazil? International Journal of Business and Management Review, Vol.6, No.1, 19.

Indrayani, I., \& Ramadhanty, A. (2020, February). Strategi Apple Inc. Dalam Penguasaan Pasar Produk Teknologi di Indonesia Tahun 2015-2019. Journal Ilmu dan Budaya, Vol.41, No. 67, 7917.

Indrayani, I., \& Ramadhanty, A. (2020, February). Strategi Apple Inc. Dalam Penguasaan Pasar Produk Teknologi di Indonesia Tahuin 2015-2019. Jurnal Ilmu dan Budaya, Vol.41, No. 67, 7919-7920.

Indrayani, I., \& Ramadhanty, A. (2020, February). Strategi Apple Inc. Dalam Penguasaan Pasar Produk Teknologi di Indonesia Tahun 2015-2019. Jurnal Ilmu dan Budaya, Vol.41, No. 67, 7923-7925.

Jane, O. (2012). Proses Internasionalisasi Perusahaan : Desain Strategi \& Organisasi (Studi kasus UKM di Kota Bandung). Research Reports-Humanities and Social Science, Vol.1 , 6-7.

Johanson, J., \& Vahlne, J.-E. (1997, March 01 ). The Internationalization Process Of The Firm-A Model Of Knowledge Development and Increasing Foreign Market Commitments. Journal of International Business, Vol. 8, No. 1, 23. 
Mayrhofer, U., \& Prange, C. (2017, November 20 ). Multinational Corporations (MNCs) and Enterprises (MNEs). Journal on Management, 3-6.

Munandar, I., \& Tambunan, A. S. (2018). AudioVisual di Platform Digital: Studi Pada Youtube, Netflix, dan Spotify. Balai Pendidikan dan Pelatihan Tambang Bawah Tanah, No 17/32, 5-6.

Nugroho, Y. (2017, December ). Analisis Kelayakan Dibuka Akses di Indonesia Ditinjau Dari Regulasi Telekomunikasi. e-Proceeding of Management, Vol.4, No.3 , 5.

Satriadi, N. P. (2014). An Analysis Translation Procedures On Sony Ericsson Live With Walkman Startup Guide. E-Journal English Education, Vol.2, No. 1, 32-33.

Scarlata, A. (2020: , July 17). New forms of internationalization? The impact of Netflix in Australia. Journal of Media International Australia, Vol. 177(Issue 1), 1-2.

Tanwar, R. (2013, November 11). Porter's Generic Competitive Strategies. IOSR Journal of Business and Management, Vol.15(Issue 1), 11.

\section{Papers, Theses, Dissertations, Research Reports:}

Fuzta, A. (2016). Internasionalisai Kerajinan Ban Bekas (Studi Kasus Pada Komunitas Sapu, Kelurahan Randuacir, Kecamatan Argomulyo, Kota Salatiga). Thesis of Magister Studi Pembangunan Program: Pascasarjana UKS, Salatiga.

Kusuma, S. D. (2019). Strategis Bisnis Perusahaan Hiburan Sebagai Instrumen Diplomasi : Studi Pada Perusahaan SM Entertainment di Korea Selatan. Paper presented at Universitas Muhammadiyah Malang, Hubungan Internasional. Malang: Eprints UMM.

Nachum, L., \& Zaheer, S. (2002, June). MNEs in the Digital Economy. The University of Cambridge. Centre for Business Research.

NST, E. D. (2014). The Influence of MNCs on Automotive Policy Indonesia Through A Low Cost Green Car (LCGC) Program 2011-2013. Paper presented at University Muhammadiyah Of Yogyakarta, International Relations. Yogyakarta: Thesis UMY.

Kurniananda, N., \& Jaludallasa, S. R. (2020). Makalah Perusahaan Multinasional. Paper at Universitas Dian Nuswantoro Semarang, Economy and Businesse, Semarang. 


\section{Internet (Individual Work)}

Rita. (2019, February 26). Competitive Advantage. (Online). Retrieved March 2021, from Binus University Business

School:https://bbs.binus.ac.id/gbm/2019/02/26/competitive-advantage/

\section{Internet (Website)}

Abbot, A. (2020, December 1). Top 15 Netflix Competitors \& Alternatives. Retrieved March 2021, from Business Strategy Hub: https://bstrategyhub.com/top-netflix-competitorsalternatives/

Alexander, J. (2020, April 22). Netflix promises subscribers it won't run out of new content while people are stuck at home. Retrieved 2021 June, from The Verge: https://www.theverge.com/2020/4/22/21231023/netflix-tv-shows-movies-new-2020pandemic-production-disney-universal-warner-bros-sony

Aulia. (2021, March 18). Harga Paket Netflix Indonesia Terbaru 2021 (Basic, Standar, dll). Retrieved March 2021, from Daftar Paket: https://daftarpaket.co.id/paket-netflixterbaru/

Clinten, B. (2020, July 7). Telkom IndiHome dan Telkomsel Resmi Buka Blokir Netflix . Retrieved March 2021, from Kompas.com: https://tekno.kompas.com/read/2020/07/07/14190027/telkom-indihome-dantelkomsel-resmi-buka-blokir-netflix

Damar, A. M. (2021, January 21). Disney Plus Hotstar Ungguli Netflix di Indonesia Soal Jumlah Pelanggan. Retrieved March 2021, from Liputan 6: https://www.liputan6.com/tekno/read/4462440/disney-plus-hotstar-ungguli-netflix-diindonesia-soal-jumlah-pelanggan\#

Dean, B. (2021, February 25). Netflix Subscriber and Growth Statistics: How Many People Watch Netflix in 2021? Retrieved June 2021, from Back Linko: https://backlinko.com/netflix-users

Eka, R. (2020, January 17). Untung Rugi Pemblokiran Netflix di Indonesia. Retrieved March 2021, from Daily Social: https://dailysocial.id/post/untung-rugi-pemblokiran-netflixdi-indonesia 
Grothaus, M. (2020, March 13). So far, Netflix is surviving the coronavirus crisis better than most media and tech companies. Retrieved March 2021, from Fast Company: https://www.fastcompany.com/90477105/so-far-netflix-is-surviving-the-coronaviruscrisis-better-than-most-media-and-tech-companies

Iskandar. (2016, January 29). 6 Fakta Netflix Diblokir di Indonesia. Retrieved March 2021, from Liputan 6 : https://www.liputan6.com/tekno/read/2423763/6-fakta-netflixdiblokir-di-indonesia\#

Jamaludin, F. (2016, January 9). Netflix masuk Indonesia, ini tanggapan industri film di Tanah Air. Retrieved March 2021, from Techno Id:

https://www.techno.id/apps/netflix-masuk-indonesia-ini-tanggapan-industri-film-ditanah-air-160109d.html

Jayani, D. H. (2019, August 13). Berapa Pelanggan Streaming Netflix di Indonesia?

Retrieved March 2021, from Databoks Katadata: https://databoks.katadata.co.id/datapublish/2019/08/13/berapa-pelanggan-streamingnetflix-di-indonesia

Jemadu, L. (2021, January 24). Jumlah Pelanggan Netflix di Indonesia di bawah Disney+ dan Viu. Retrieved March 2021, from Suara: https://www.suara.com/tekno/2021/01/24/070500/jumlah-pelanggan-netflix-diindonesia-di-bawah-disney-dan-viu

Kompas. (2020, July 07). Telkom IndiHome dan Telkomsel Resmi Buka Blokir Netflix . Retrieved March 2021, from Kompas.com: https://tekno.kompas.com/read/2020/07/07/14190027/telkom-indihome-dantelkomsel-resmi-buka-blokir-netflix

Kontan. (2020, August 17). Persaingan bisnis semakin ketat, Netflix akan memperluas konten lokal. Retrieved March 2021, from Internasional Kontan: https://internasional.kontan.co.id/news/persaingan-bisnis-semakin-ketat-netflix-akanmemperluas-konten-lokal

Kumparan. (2020, July 9). Cara Langganan Netflix Tanpa Kartu Kredit, tapi Bukan Ilegal! Retrieved March 2021, from Kumparan Tech: https://kumparan.com/kumparantech/cara-langganan-netflix-tanpa-kartu-kredit-tapibukan-ilegal-1t1O7nfbhkR/full 
Leba, E. E. (2020, April 23). Selama Pandemi Covid-19, Pelanggan Baru Netflix Mencapai 16 Juta. Retrieved March 2021, from Kompas ID:

https://www.kompas.id/baca/hiburan/2020/04/23/netflix-tambah-16-juta-pelangganbaru-selama-pandemi-covid-19/

Lovely, S. (2018, November 13). Netflix's Original Content Strategy Is Paying Off. Retrieved March 2021, from The Motley Fool:

https://www.fool.com/investing/2018/11/13/netflixs-original-content-strategy-ispaying-off.aspx

Pertiwi, W. K. (2018, October 20). Netflix Resmi Sediakan Menu dan "Subtitle" Bahasa Indonesia". Retrieved March 2021, from Kompas.com:

https://tekno.kompas.com/read/2018/10/20/18090037/netflix-resmi-sediakan-menudan-subtitle-bahasa-indonesia

Rosenberg, E. (2021, March 9). Why Netflix Content Is Different Abroad. Retrieved March 2021, from Investopedia:

https://www.investopedia.com/articles/investing/050515/why-netflix-contentdifferent-other-countries.asp

Ruether, T. (2020, May 21). VOD Streaming: What It Is and How It Relates to OTT. Retrieved May 2021, from WOWZA media system: https://www.wowza.com/blog/vod-streaming-what-it-is-and-how-it-relates-to-ott

Saxena, D. (2020, April 20). What is Transnational Strategy in International Business?

Retrieved June 2021, from Super Heuristic: https://www.superheuristics.com/what-istransnational-strategy/\#tab-con-0

Stephanie, C. (2020, September 14). Perbandingan Harga Langganan Netflix, Viu, Amazon Prime, dan Disney Plus di Indonesia. Retrieved March 2021, from Kompas.com: https://tekno.kompas.com/read/2020/09/14/16210007/perbandingan-harga-langganannetflix-viu-amazon-prime-dan-disney-plus-di?page=all

Times, T. S. (2021, January 21). Netflix keeps growing in Covid-19 pandemic, tops 200m subscribers. Retrieved from The Straits Times: https://www.straitstimes.com/life/entertainment/netflix-keeps-growing-in-pandemictops-200m-subscribers 
Virk, R. (2018, January 28). How blockchain could kill both cable and Netflix. Retrieved June 2021, from Venture Beat: https://venturebeat.com/2018/01/28/how-blockchaincould-kill-both-cable-and-netflix/

Wibisono, N. (2016, February 23). Netflix di Indonesia, Dijegal Sebelum Berkembang . Retrieved March 2021, from Tirto ID: https://tirto.id/netflix-di-indonesia-dijegalsebelum-berkembang-Dd 